\title{
Prediction of metaphase II oocytes according to different serum Anti-Müllerian hormone (AMH) levels in antagonist ICSI cycles
}

\author{
Joyce B da Silva ${ }^{1}$, Tatiana R Panaino ${ }^{1}$, Maria A Tamm ${ }^{1}$, Paloma Lira ${ }^{1}$, Patricia C F Arêas ${ }^{1}$, Ana C A Mancebo ${ }^{1}$, \\ Marcelo M de Souza ${ }^{1}$, Roberto A Antunes ${ }^{1}$, Maria do Carmo B de Souza ${ }^{1}$
}

\author{
${ }^{1}$ Fertipraxis Reproduction Center, Rio de Janeiro, RJ, Brazil
}

\begin{abstract}
Objective: This paper aims to assess a qualitative aspect of ovarian response in terms of metaphase II oocytes according to different serum Anti-Müllerian hormone levels in antagonist ICSI cycles. A prediction index might contribute to the individualization of care.

Methods: This observational study looked into 287 antagonist ICSI cycles carried out with patients treated in a single center between January of 2012 and January of 2016. Serum AMH and subgroup analyses were performed based on five AMH ranges $(\leq 0.3 \mathrm{ng} / \mathrm{mL} ;>0.3$ and $\leq 0.7$ $\mathrm{ng} / \mathrm{mL} ;>0.7$ and $\leq 1.0 \mathrm{ng} / \mathrm{mL} ;>1.0$ and $<3.0 \mathrm{ng} / \mathrm{mL} ; \geq$ $3.0 \mathrm{ng} / \mathrm{mL}$ ). The variables analyzed included patient age; serum FSH and antral follicle count at the start of the cycle; number of stimulation days and number follicles $\geq 15$ $\mathrm{mm}$ on hCG day; number of oocytes retrieved and number of metaphase II oocytes.

Results: $\mathrm{AMH}$ is a better predictor of ovarian response to controlled ovarian stimulation than AFC or serum FSH, while age is an independent marker. AMH levels $\leq 0.70$ (patients with poor prognosis) were observed in 140 patients $(48.7 \%)$. Patients within this AMH level range accounted for $92 \%$ of the 24 failed cycles (cancelled cycles, no oocytes or immature oocytes retrieved).

Conclusion: AMH predicts the quality of ovarian response to stimulation, regardless of patient age. Women with $\mathrm{AMH}$ levels $\geq 1.0$ and $\leq 3.0 \mathrm{ng} / \mathrm{mL}$ are probably normal responders with good prognosis. Clinical application relies on the examination of the data from each individual center and on the establishment of correlations between AMH levels and ovarian response in the form of metaphase II oocytes.
\end{abstract}

Keywords: Anti-Müllerian hormone (AMH), metaphase II oocytes, ovarian response, controlled ovarian stimulation, IVF outcome.

\section{INTRODUCTION}

One of the most difficult aspects of individualizing assisted reproduction care is the identification of the actual ovarian reserve and counseling patients with very low chances of achieving pregnancy (Lee et al., 2011). Ovarian reserve tests provide knowledge of a patient's possible response, permitting the management of the appropriate gonadotropin dosages (Fleming et al., 2013). Several parameters have been postulated as predictors of ovarian response, including serum markers (FSH, inhibin B, 17-B-estradiol, and anti-Müllerian hormone) and ultrasound variables (ovarian volume, measurement of antral follicles and ovarian stromal blood flow). Even after adjustment for chronological age, antral follicle count (AFC) and serum AMH correlate with ovarian primordial follicle number (Hansen et al., 2011; Aydin et al., 2015).

The release of AMH from ovarian granulosa cells leads to measurable serum levels, which are proportional to the number of developing follicles in the ovaries and appear to regulate early follicle development (La Marca et al., 2005). $\mathrm{AMH}$ is expressed in small and large pre antral follicles and in small antral follicles, the latter of which one of the main contributors to $\mathrm{AMH}$ serum levels. Initial recruitment of ovarian follicles is a continuous process, whereas cyclic recruitment is driven by a rise in FSH serum levels at the end of a previous menstrual cycle (Broekmans et al., 2008). The expression of the AMH receptor in granulosa cells suggests that it may play a role in ovarian physiology (La Marca \& Volpe, 2006), and the main physiological role of AMH in the ovary seems to be the inhibition of the early stages of follicular development (Visser \& Themmen, 2005). Detectable at birth, AMH levels rise in the weeks after birth to reach a peak after puberty (Bergadá et al., 2006; Guibourdenche et al., 2003). In prepubertal girls, $\mathrm{AMH}$ levels seem to be low with a tendency to rise towards the onset of puberty, and the hormone continues to be expressed in the growing follicles in the ovary until they have reached the size and differentiation state at which they are to be selected for dominance by the action of pituitary $\mathrm{FSH}$. In adult women, serum AMH levels have been shown to decline gradually with age, as a sign of follicular exhaustion, becoming undetectable in menopause (Van Rooij et al., 2005).

AMH seems to exhibit a fairly stable consistent pattern of expression during the menstrual cycle, making it an attractive determinant of ovarian activity (La Marca \& Volpe, 2006; Hazout et al., 2004). AMH shows less intra-individual fluctuation than AFC and basal FSH levels, and might be a better, cycle-independent parameter in assessing the ovarian reserve (Van Disseldorp et al., 2010; Verhagen et al., 2008; La Marca \& Volpe, 2006; La Marca et al., 2013); however, AMH levels may decrease if measured during COS (Hamdine et al., 2015).

The decrease in AMH levels that occurs with aging may be noted before changes in other age-related variables ( $L a$ Marca et al., 2009), suggesting serum AMH levels may be a better marker of ovarian aging. AMH assays are being developed to demonstrate greater sensitivity, and they are likely to show greater value in this regard (Fleming et al., 2015).

In the last few years published studies have described the clinical application of AMH measurement in the prediction of quantitative and qualitative ovarian response in assisted reproductive technologies (ART). There is an association between $\mathrm{AMH}$ and oocyte yield after ovarian stimulation, and the hormone has been shown to be a strong predictor of ovarian response to gonadotropins, whether satisfactory, poor or excessive, cycle cancellation, and of the quality of oocytes and embryos (La Marca et al., 2005; Kavoussi et al., 2015).

A significant positive correlation has been described between serum AMH and the number of oocytes retrieved and mature oocytes. This correlation was considerably stronger than the associations found with other ovarian reserve markers such as serum FSH and estradiol (Seifer et al., 2002). Patients with undetectable AMH levels have been shown to successfully obtain oocytes at the time of retrieval and even to achieve ongoing pregnancy (Fraisse et al., 2008; Tokura et al., 2013). Therefore, a lower limit of $\mathrm{AMH}$ below which patients should not expect to have 
any ovarian response has not been established (Burks et al., 2015). A circulating AMH level of $0.7 \mathrm{ng} / \mathrm{ml}$ has been claimed to be the threshold value for poor ovarian response to controlled ovarian stimulation (COS), whereas levels below $0.1-0.35 \mathrm{ng} / \mathrm{ml}$ have been associated with high risk of cycle cancellation due to extremely poor response (Revelli et al., 2016).

\section{MATERIAL AND METHODS}

This observational study looked into 287 antagonist ICSI cycles carried out with patients treated in a single center between January of 2012 and January of 2016. The maximum time interval between serum sampling and the start of COS was 12 months. Eighty per cent of the measurements were performed in the same laboratory. The following test kits were used to assess AMH levels: 2012 and 2013 - AMH Gen II ELISA (Beckman Coulter), an enzymatically amplified two-site immunoassay; 2014 - dual monoclonal antibodies in a chemiluminescent immunoassay (Quest Diagnostics); since 2015 - EletroChemiLuminescence, a technology developed by Roche for immunoassay detection (ELECSYS). The lower AMH detection limit was $0.012 \mathrm{ng} / \mathrm{mL}$. The patients enrolled in the study consented to having their data discussed in scientific papers prior to the start of the cycles. Since this was a study based on data collected from patient charts, no further inquiries were made with the Ethics Committee.

Individual dosages were adjusted based on AMH levels. The patients were not pretreated with either oral contraceptives or estradiol. According to local protocol, stimulation began on day 2 or 3 of the cycle; most protocols used recombinant FSH (150-225 IU per day), with LH added for women $\geq 35$ years ( $2: 1$ ratio $\mathrm{FSH} / \mathrm{LH}$ ) and aromatase inhibitors whenever $\mathrm{AMH}<1 \mathrm{ng} / \mathrm{mL}$ ( $5 \mathrm{mg}$ per day, until the rhCG day). A daily $\mathrm{GnRH}$ antagonist dose of $0.25 \mathrm{mg}$ was initiated based on a flexible protocol once a follicle $\geq$ $14 \mathrm{~mm}$ in diameter was seen in the ultrasound scan; antagonist therapy was continued until hCG administration. Gonadotropin doses could be adjusted from start of antagonist therapy. When at least one follicle was $>18$ and two follicles were $\geq 16 \mathrm{~mm}$ in diameter, $250 \mathrm{mcg}$ of recombinant human Chorionic Gonadotropin (Ovidrel ${ }^{\circledR}$, Merck Serono SA.) was administered to induce final oocyte maturation. In patients at risk of OHSS, $0.2 \mathrm{mg}$ triptorelin (Gonapepty ${ }^{\circledR}$, Ferring Farmaceuticals) was used. Oocyte retrieval was performed under transvaginal ultrasound guidance 35 hours after ovulation induction.

The method we use in oocyte preparation and analysis has been described previously (Souza et al., 2009). This study focused solely on the prediction of metaphase II oocytes. Therefore, it included oocyte cryopreservation cycles, but fertilization, implantation and pregnancy rates on IVF/ICSI cycles were not addressed. Subgroup analyses were performed according to five AMH ranges: Group 1: $\leq$ $0.3 \mathrm{ng} / \mathrm{mL}$ (probably negligible response); Group $2:>0.3$ and $\leq 0.7 \mathrm{ng} / \mathrm{mL}$ (expected lower response); Group 3: > 0.7 and $\leq 1.0 \mathrm{ng} / \mathrm{mL}$ (possibly intermediate response); Group 4: $>1.0$ and $<3.0 \mathrm{ng} / \mathrm{mL}$ (normal response); and Group 5: $\geq 3.0 \mathrm{ng} / \mathrm{mL}$ (high response). Observed variables included patient age; serum FSH and antral follicle count (AFC) at the start of the cycle; number of stimulation days; number follicles $\geq 15 \mathrm{~mm}$ on hCG day; number of oocytes retrieved and of metaphase II oocytes. Statistical analysis was performed by ANOVA. Significance was attributed to events with a $P<0.05$.

\section{RESULTS}

The patients were divided into five groups based on the percentile ranks of AMH levels; the groups had 64, 76, 32, 86 and 29 patients, respectively. Canceled cy- cles, age, duration of stimulus, FSH levels, antral follicles, follicles $\geq 15 \mathrm{~mm}$ on hCG day, number of total oocytes, and number of metaphase II oocytes were found to be associated with AMH levels (Table 1).

There were no differences between groups in relation to the BMI. Female age was found to be an independent predictor of ovarian reserve. Statistical differences were found when groups 1,2 and 3 were compared (mean age 38 years) to group 5 (age 35.48 years), $P<0.05$. No differences were seen between group 4 (age 37.23 years) and the other groups.

The serum basal FSH levels of patients in the group with $\mathrm{AMH}$ levels $\leq 0.3 \mathrm{ng} / \mathrm{mL}$ were statistically different from the levels seen in the other groups. Indeed, poor responder groups differed mildly from each other but significantly when compared to normal or high responders.

No statistically significant difference was seen for antral follicle count (AFC) when groups 1 and 2 were compared (poorer prognosis groups) to group 3, but there was difference between groups 1 and 2 and groups $4(P<$ $0.001)$ and $5(P<0.001)$. Interestingly, no difference was seen in AFC between groups 3 and 4 whereas all groups were statistically different from group $5(P<0.001)$.

In terms of duration of stimulus, no difference was found between groups, but the total amount of $\mathrm{FSH}$ required was significantly lower in group 1 ( $\leq 0.3 \mathrm{ng} \mathrm{mL}$ ).

Another interesting finding was the statistical difference observed when groups 1 and 2 were compared to groups 3 and 4 for number of follicles $\geq 15 \mathrm{~mm}$ on hCG day $(P<0.01)$. Groups 1 and 2 had approximately 3 and 5 follicles $\geq 15 \mathrm{~mm}$, respectively, while groups 3 and 4 had 6 and 7 follicles, respectively. No difference was seen when groups 3 and 4 were compared. However, there was a significant difference when the number of follicles seen in groups 1,3 and 4 was compared to the number observed in group $5(P<0.001)$.

There was a significant difference in the total number of oocytes retrieved and metaphase II oocytes when groups 1 and 2 were compared $(P<0.05)$, as also seen when group 1 was compared to groups 4 and $5(P<0.001)$. No difference was observed between groups 2 and 3 in this regard. However, a difference was seen in the total number of oocytes retrieved when groups 2 and 3 were compared to groups 4 and 5 . And, as expected, there was a statistical difference between groups 4 and 5 in this aspect. There was no statistical difference in the number of metaphase II oocytes between groups 2, 3 and 4 . However, when these groups were compared to group 5, an expected statistically significant difference was verified $(P<0.001)$. No differences were observed between groups 1 and 3 .

Table 2 shows treatment indications for all cases. Every group had patients willing to have their oocytes frozen, even when the prognosis was poor. Some patients had more than one treatment indication.

AMH levels $\leq 0.70$ (patients with poor prognosis) were observed in 140 patients $(48.7 \%)$. Patients within this AMH level range accounted for $93 \%$ of the failed cycles (15 patients in group $1 ; 11$ in group 2 ; one in group 3 ; and one in group 4). These numbers include cancelled cycles and patients with no oocytes or immature oocytes retrieved (Table 3).

\section{DISCUSSION}

If $\mathrm{AMH}$ measurement is proposed to all women prior to the start of an IVF program, a clear definition of cutoff values for the prediction of poor and hyper-response is required to design treatment strategies. Nelson et al. (2009) also considered most of these aspects in a prospective study.

The main finding of this study was the association between AMH levels and retrieved metaphase II oocytes. AMH 
Table 1. Parameters and ovarian stimulation outcomes according to AMH levels.

\begin{tabular}{|c|c|c|c|c|c|c|}
\hline Parameter & $\begin{array}{c}\text { Group } 1 \\
\text { AMH } \leq 0.30\end{array}$ & $\begin{array}{c}\text { Group } 2 \\
>0.30 \text { AMH } \\
\leq 0.70\end{array}$ & $\begin{array}{c}\text { Group } 3 \\
>0.70 \text { AMH } \\
\leq 1.0\end{array}$ & $\begin{array}{c}\text { Group } 4 \\
>1.0 \text { AMH } \\
<3.0\end{array}$ & $\begin{array}{c}\text { Group } 5 \\
A M H \geq 3.0\end{array}$ & P-value \\
\hline $\begin{array}{l}\text { Started } \\
\text { cycles ( } 287 \text { total) }\end{array}$ & 64 & 76 & 32 & 86 & 29 & \\
\hline BMI $\left(\mathrm{kg} / \mathrm{m}^{2}\right)$ & $\begin{array}{c}22.95 \\
\pm \\
2.77\end{array}$ & $\begin{array}{c}23.95 \\
\pm \\
3.84\end{array}$ & $\begin{array}{c}23.79 \\
\pm \\
3.41\end{array}$ & $\begin{array}{c}23.23 \\
\pm \\
3.71\end{array}$ & $\begin{array}{l}24.08 \\
\pm \\
3.97\end{array}$ & NS \\
\hline Age & $\begin{array}{l}37.83 \\
\pm \\
4.11^{a}\end{array}$ & $\begin{array}{c}38.61 \\
\pm \\
3.67 \mathrm{~b}\end{array}$ & $\begin{array}{c}38.15 \\
\pm \\
3.04^{c}\end{array}$ & $\begin{array}{l}37.23 \\
\pm \\
3.64\end{array}$ & $\begin{array}{c}35.48 \\
\pm \\
3.97 \mathrm{abc}\end{array}$ & $a b c<0.05$ \\
\hline Serum FSH & $\begin{array}{c}12.45 \\
\pm \\
8.24^{\text {abcd }}\end{array}$ & $\begin{array}{c}8.95 \\
\pm \\
5.54^{a}\end{array}$ & $\begin{array}{c}7.99 \\
\pm \\
3.86^{b}\end{array}$ & $\begin{array}{c}7.40 \\
\pm \\
3.11^{\mathrm{c}}\end{array}$ & $\begin{array}{c}6.81 \\
\pm \\
2.11^{\mathrm{d}}\end{array}$ & $\begin{array}{c}\mathrm{ab}<0.01 \\
\mathrm{~cd}<0.001\end{array}$ \\
\hline AFC & $\begin{array}{c}6.75 \\
\pm \\
3.47^{\mathrm{ab}} \\
\end{array}$ & $\begin{array}{c}9.11 \\
\pm \\
4.93^{\text {cde }}\end{array}$ & $\begin{array}{c}9.53 \\
\pm \\
3.74^{f}\end{array}$ & $\begin{array}{c}12.60 \\
\pm \\
5.24^{\mathrm{acg}}\end{array}$ & $\begin{array}{c}17.58 \\
\pm \\
7.64^{\text {bdefg }}\end{array}$ & abcefg $<0.001$ \\
\hline Stimulation days & $\begin{array}{c}9.59 \\
\pm \\
1.73\end{array}$ & $\begin{array}{c}9.41 \\
\pm \\
1.74\end{array}$ & $\begin{array}{c}10.03 \\
\pm \\
1.53\end{array}$ & $\begin{array}{l}9.24 \\
\pm \\
1.50\end{array}$ & $\begin{array}{l}8.93 \\
\pm \\
1.10\end{array}$ & NS \\
\hline $\begin{array}{l}\text { FSH } \\
\text { administered (IU) }\end{array}$ & $\begin{array}{c}1673.66 \\
\pm \\
538.88\end{array}$ & $\begin{array}{c}1744.57 \\
\pm \\
707.02\end{array}$ & $\begin{array}{c}1805.64 \\
\pm \\
562.79\end{array}$ & $\begin{array}{c}1725.72 \\
\pm \\
623.76\end{array}$ & $\begin{array}{c}1620.27 \\
\pm \\
559.93\end{array}$ & NS \\
\hline $\begin{array}{l}\text { Fol. } \geq 15 \mathrm{~mm} \\
\text { on hCG day }\end{array}$ & $\begin{array}{c}3.64 \\
\pm \\
2.26^{\mathrm{abc}}\end{array}$ & $\begin{array}{c}5.36 \\
\pm \\
3.64^{\text {de }}\end{array}$ & $\begin{array}{c}6.34 \\
\pm \\
3.98^{\mathrm{adf}}\end{array}$ & $\begin{array}{c}7.37 \\
\pm \\
3.60^{\text {beg }}\end{array}$ & $\begin{array}{c}11.13 \\
\pm \\
4.22^{\mathrm{cfg}}\end{array}$ & $\begin{array}{l}\text { bcefg }<0.001 \\
\quad \text { ad } 0.01\end{array}$ \\
\hline $\begin{array}{l}\text { No. of oocytes } \\
\text { retrieved }\end{array}$ & $\begin{array}{c}3.27 \\
\pm \\
3.14^{\mathrm{abc}}\end{array}$ & $\begin{array}{c}6.23 \\
\pm \\
6.85^{\text {ade }}\end{array}$ & $\begin{array}{c}5.87 \\
\quad \pm \\
3.89^{\mathrm{fg}}\end{array}$ & $\begin{array}{c}9.25 \\
\pm \\
5.10^{\text {bdfh }}\end{array}$ & $\begin{array}{c}16.96 \\
\pm \\
7.21^{\text {cegh }}\end{array}$ & $\begin{aligned} \text { af } & <0.05 \\
{ }^{d} & <0.01 \\
\text { bcegh } & <0.001\end{aligned}$ \\
\hline $\begin{array}{l}\text { No. of metaphase } \\
\text { II oocytes }\end{array}$ & $\begin{array}{c}1.89 \\
\pm \\
2.15^{\mathrm{abc}}\end{array}$ & $\begin{array}{c}4.34 \\
\pm \\
5.96^{\mathrm{ad}}\end{array}$ & $\begin{array}{c}4.09 \\
\pm \\
3.12^{\mathrm{e}}\end{array}$ & $\begin{array}{c}6.30 \\
\pm \\
4.40^{\mathrm{bf}}\end{array}$ & $\begin{array}{c}11.44 \\
\pm \\
6.35^{\text {cdef }}\end{array}$ & $\begin{aligned} \mathrm{a} & <0.05 \\
\text { bcdef } & <0.001\end{aligned}$ \\
\hline
\end{tabular}

Table 2. Indication of treatment according group.

\begin{tabular}{|c|c|c|c|c|c|}
\hline & Group 1 & Group 2 & Group 3 & Group 4 & Group 5 \\
\hline Ovarian factor & $37 *$ & $38 *$ & 10 & 19 & $10 *$ \\
\hline Tubal & 0 & $6 * *$ & 3 & $15 * *$ & 2 \\
\hline Endometriosis & 6 & 2 & 4 & 8 & 3 \\
\hline Male & $6 *$ & $7 * / * * *$ & 5 & $18 * * *$ & $6 *$ \\
\hline Unexplained & 5 & 13 & 2 & 10 & 6 \\
\hline Social & 1 & 2 & 0 & 1 & 2 \\
\hline Cryopreservation & 8 & 9 & 8 & 12 & 2 \\
\hline Other & 3 & 2 & 0 & 4 & \\
\hline
\end{tabular}

levels indicated that $48.7 \%$ of the cycles involved women with diminished ovarian reserves, and $13.6 \%$ of the patients were good candidates for cryopreservation. This information confirms the need of good counseling when it comes to tailoring the stimulation protocol. Much effort has been made to identify patients with good prognosis based on AMH levels (Souza et al., 2014), as La Marca et al. (2010), Hamdine et al. (2015), and others have pointed out.

A statistically significant difference in mean serum $\mathrm{AMH}$ levels and age of female patients was identified for $\mathrm{AMH}$ levels $\leq 0.7$ when compared to other groups. This is a relevant point in our practice, as $40 \%$ of our patients are aged 38 years or older. And the same applies to the Latin American Registry, in which $70 \%$ of the patients are aged 35 years and older (Zegers-Hochschild et al., 2016).

La Marca et al. (2010) predicted normal response for individuals with AMH levels $\geq 0.66$ and $<1.99 \mathrm{ng} /$ $\mathrm{mL}$ and high response for subjects with AMH levels $\geq$ $1.99 \mathrm{ng} / \mathrm{mL}$. The AMH levels of our group of normal responders ranged from 1 to $3 \mathrm{ng} / \mathrm{mL}$, while high responders (at risk to OHSS) had AMH levels above $3 \mathrm{ng} / \mathrm{mL}$. Our failed stimulations situated mainly in the groups 
Table 3. Cycle outcomes according to AMH levels.

\begin{tabular}{|c|c|c|c|c|}
\hline & Initiated cycles & Cancelled cycles & Immature oocytes & No oocytes \\
\hline $\begin{array}{c}\text { Group 1 } \\
\leq 0.3\end{array}$ & 64 & 8 & 3 & 3 \\
\hline $\begin{array}{c}\text { Group 2 } \\
0.3 \text { and } \leq 0.7\end{array}$ & 76 & 3 & 3 & 4 \\
\hline $\begin{array}{c}\text { Group 3 } \\
0.7 \text { and } \leq 1.0\end{array}$ & 32 & 0 & 1 & 0 \\
\hline $\begin{array}{c}\text { Group 4 } \\
1.0 \text { and } \leq 3.0\end{array}$ & 86 & 0 & 0 & 1 \\
\hline $\begin{array}{c}\text { Group 5 } \\
>3.0\end{array}$ & 29 & 0 & 0 & 0 \\
\hline
\end{tabular}

with $\mathrm{AMH}$ levels $\leq 0.7 \mathrm{ng} / \mathrm{mL}$, and oocytes were retrieved even with very low levels. Reichman et al. (2014) also found, after studying 2,760 patients and 4,072 cycles, that AMH positively correlates with the number of oocytes retrieved and is a robust predictor of COS IVF cycle failure.

One of the drawbacks of our AMH level measurement protocol (Iliodromiti et al., 2014; Rustamov et al., 2014) is that we had three different assays used during the course of the study. Assays have become more robust with time and AFC values remained stable, as the protocol was performed in the same center and using the same technique. In this study, patients with poorer prognosis had statistically different AFC and basal FSH levels when compared to women in good prognosis groups (normal and high responders). AFC alone did not yield significant differences between the three groups with poorer prognosis.

Different indications for ART in the different AMH level groups might explain the cycles without transfer (Table 2). Patients with lower AMH levels underwent IVF/ ICSI treatment mostly because of a detected reduced ovarian reserve. The indication of ART for patients with high AMH levels was usually based on the presence of anovulatory cycles due to PCOS. The group with normal AMH levels included mainly ovulatory women with other IVF/ICSI indications such as male factor, tubal factor or unexplained infertility, and endometriosis, as described by other authors (Gomez et al., 2015).

The present study strongly supports previously published papers discussing the prognostic value of AMH levels upon total number of oocytes and oocyte quality. A possible limitation in this study is the time interval between serum sampling and start of COS. However, it is rather unlikely that such a time interval has impacted our results, as a time interval up to 12 months between serum sampling and initiation of stimulation has been shown not to affect the predictive ability of AMH (Polyzos et al., 2013).

Anti-Müllerian hormone allows for better selection and individualization of stimulation protocols, and should be added to the toolkit of assisted reproduction physicians as indicated by Fleming et al., 2015. Our study found a significant positive correlation between serum AMH levels and the number of oocytes retrieved and mature oocytes. AMH levels were a considerably stronger marker of ovarian reserve than serum FSH, as also reported by Seifer et al. (2002).

Patients with undetectable AMH levels have had oocytes retrieved and have been able to achieve ongoing pregnancy (Fraisse et al., 2008; Tokura et al., 2013). Therefore, a lower limit of AMH below which patients should not expect to have any ovarian response has not been established (Burks et al., 2015). A circulating AMH level $\leq 0.7 \mathrm{ng} /$ $\mathrm{mL}$ deserves attention for having poor ovarian response to $\cos$ and presenting a higher risk of cycle failure.

\section{CONCLUSION}

$\mathrm{AMH}$ is particularly useful to predict the quality of ovarian response to stimulation, independently from patient age. Women with AMH levels $\geq 1.0$ and $\leq 3.0 \mathrm{ng} /$ $\mathrm{mL}$ are probably normal responders with good prognosis. Clinical application depends on individual centers examining their own data, correlating $\mathrm{AMH}$ levels and ultimate ovarian response in the form of metaphase II oocytes.

\section{CONFLICT OF INTERESTS}

No conflict of interest have been declared.

\section{Corresponding author:}

Maria do Carmo Borges de Souza

Fertipraxis Centro de Reprodução

Rio de Janeiro, Brazil

E-mail: mariadocarmo@fertipraxis.com.br

\section{REFERENCES}

Aydin GA, Yavuz A, Terzi H, Kutlu T. Assessment of the relationship of basal serum anti-mullerian hormone levels with oocyte quality and pregnancy outcomes in patients undergoing ICSI. Iran J Reprod Med. 2015;13:231-6.

Bergadá I, Milani C, Bedecarrás P, Andreone L, Ropelato MG, Gottlieb S, Bergadá C, Campo S, Rey RA. Time course of the serum gonadotropin surge, inhibins, and anti-Müllerian hormone in normal newborn males during the first month of life. J Clin Endocrinol. Metab. 2006; 91: 4092-8.

Broekmans FJ, Visser JA, Laven JSE, Broer SL, Themmen APN, Fauser BC. Anti-Mullerian hormone and ovarian dysfunction. Trends Endocrinol Metab. 2008;19:340-7.

Burks HR, Ross L, Opper N, Paulson E, Stanczyk FZ, Chung $\mathrm{K}$. Can highly sensitive antimüllerian hormone testing predict failed response to ovarian stimulation? Fertil Steril. 2015;104:643-8.

Fleming R, Broekmans F, Calhaz-Jorge C, Dracea L, Alexander $\mathrm{H}$, Nyboe Andersen A, Blockeel C, Jenkins J, Lunenfeld B, Platteau P, Smitz J, de Ziegler D. Can anti-Mullerian hormone concentrations be used to determine gonadotrophin dose and treatment protocol for ovarian stimulation? Reprod Biomed Online. 2013;26:431-9.

Fleming R, Seifer DB, Frattarelli JL, Ruman J. Assessing ovarian response: antral follicle count versus anti-Müllerian hormone. Reprod Biomed Online. 2015; 31:486-96.

Fraisse T, Ibecheole V, Streuli I, Bischof P, de Ziegler D. Undetectable serum anti-Müllerian hormone levels and occurrence of ongoing pregnancy. Fertil Steril. 2008;89:723. e9-11.

Gomez R, Schorsch M, Hahn T, Henke A, Hoffmann I, Seu- 
fert R, Skala C. The influence of AMH on IVF success. Arch Gynecol Obstet. 2016;293:667-73.

Guibourdenche J, Lucidarme N, Chevenne D, Rigal O, Nicolas $M$, Luton $D$, Léger J, Porquet $D$, Noël M. Anti-Müllerian hormone levels in serum from human foetuses and children: pattern and clinical interest. Mol Cell Endocrinol. 2003;211:55-63.

Hamdine O, Eijkemans MJ, Lentjes EW, Torrance HL, MackIon NS, Fauser BC, Broekmans FJ. Ovarian response prediction in $\mathrm{GnRH}$ antagonist treatment for IVF using anti-Müllerian hormone. Hum Reprod. 2015;30:170-8.

Hansen KR, Hodnett GM, Knowlton N, Craig LB. Correlation of ovarian reserve tests with histologically determined primordial follicle number. Fertil Steril. 2011;95:170-5.

Hazout A, Bouchard P, Seifer DB, Aussage P, Junca AM, Cohen-Bacrie $P$. Serum antimüllerian hormone/müllerian-inhibiting substance appears to be a more discriminatory marker of assisted reproductive technology outcome than follicle stimulating hormone, inhibin $B$, or estradiol. Fertil Steril. 2004;85:1323-29.

Iliodromiti S, Anderson RA, Nelson SM. Technical and performance characteristics of anti-Mullerian hormone and antral follicle count as biomarkers of ovarian response. Hum Reprod Update. 2015;21:698-710

Kavoussi SK, Odenwald KC, Boehnlein LM, Summers-Colquitt RB, Pool TB, Swain JE, Jones JM, Lindstrom MJ, Lebovic DI. Antimüllerian hormone as a predictor of good-quality supernumerary blastocyst cryopreservation among women with levels $<1 \mathrm{ng} / \mathrm{mL}$ versus $1-4 \mathrm{ng} / \mathrm{mL}$. Fertil Steril. 2015;104:633-6.

La Marca A, De Leo V, Giulini S, Orvieto R, Malmusi S, Giannella L, Volpe A. Anti-Mullerian hormone in premenopausal women and after spontaneous or surgically induced menopause. J Soc Gynecol Investig. 2005; 12:545-48.

La Marca A, Volpe A. Anti-Mullerian hormone (AMH) in female reproduction: is measurement of circulating $\mathrm{AMH}$ a useful tool? Clin Endocrinol (Oxf). 2006;64:603-10.

La Marca A, Broekmans, FJ, Volpe A, Fauser BC, MackIon NS; ESHRE Special Interest Group for Reproductive Endocrinology-AMH Round Table. Anti-Mullerian hormone (AMH): what do we still need to know? Hum Reprod. 2009;24:2264-75.

La Marca A, Sighinolfi G, Radi D, Argento C, Baraldi E, Artenisio $A C$, et al. Anti-Mullerian hormone (AMH) as a predictive marker in assisted reproductive technology (ART) Hum Reprod Update. 2010;16:113-30.

La Marca A, Grisendi V, Griesinger G. How much does AMH really vary in normal women? Int J Endocrinol. 2013; 2013:959487.

Lee RK, Wu FS, Lin MH, Lin SY, Hwu YM. The predictability of serum anti-Müllerian level in IVF/ICSI outcomes for patients of advanced reproductive age. Reprod Biol Endocrinol. 2011;9:115.

Nelson SM, Yates RW, Lyall H, Jamieson M, Traynor I, Gaudoin M, Mitchell P, Ambrose P, Fleming R. Anti-Müllerian hormone-based approach to controlled ovarian stimulation for assisted conception. Hum Reprod. 2009; 24:867-75.
Polyzos NP, Nelson SM, Stoop D, Nwoye M, Humaidan P, Anckaert $E$, Devroey $P$, Tournaye $H$. Does the time interval between antimullerian hormone serum sampling and initiation of ovarian stimulation affect its predictive ability in in vitro fertilization -intracytoplasmic sperm injection cycles with a gonadotropin-releasing hormone antagonist? A retrospective single-center study. Fertil Steril. 2013;2:43844.

Reichman DE, Goldschlag D, Rosenwaks Z. Value of antimüllerian hormone as a prognostic indication of in vitro fertilization outcome. Fertil Steril. 2014;101:1012-8.

Revelli A, Biasoni V, Gennarelli G, Canosa S, Dalmasso P, Benedetto $C$. IVF results in patients with very low serum AMH are significantly affected by chronological age. J Assist Reprod Genet. 2016;33:603-9

Rustamov O, Smith A, Roberts SA, Yates AP, Fitzgerald C, Krishnan M, Nardo LG, Pemberton PW. The measurement of anti-Mullerian hormone: a critical appraisal. J Clin Endocrinol Metab. 2014;99:723-32.

Seifer DB, MacLaughlin DT, Christian BP, Feng B, Shelden RM. Early follicular serum Mullerian-inhibiting substance levels are associated with ovarian response during assisted reproductive technology cycles. Fertil Steril. 2002;77:46871.

Souza MCB, Mancebo ACA, Rocha C A, Henriques CA, Souza MM, Cardoso FFO. Evaluation of two incubation environments ISO class 8 versus ISO class 5 on intracytoplasmic sperm injection cycle outcome. Fertil Steril. 2009;91:1780-4.

Souza MCB, Mancebo ACA, Silva JB, Antunes RA, Souza $M M$. Prediction of metaphase II oocytes according to diferent serum anti-Müllerian hormone $(\mathrm{AMH})$ in antagonist ICSI cycles. JBRA Assist Reprod. 2014;18:98-125.

Tokura $\mathrm{Y}$, Yoshino O, Ogura-Nose S, Motoyama H, Harada M, Osuga Y, Shimizu Y, Ohara M, Yorimitsu T, Nishii O, Kozuma S, Kawamura T. The significance of serum anti-Müllerian hormone $(\mathrm{AMH})$ levels in patients over age 40 in first IVF treatment. J Assist Reprod Genet. 2013;30:821-5.

van Disseldorp J, Lambalk CB, Kwee J, Looman CW, Eijkemans MJ, Fauser BC, Broekmans FJ.Comparison of inter and intra cycle variability of $\mathrm{AMH}$ and antral follicle counts. Hum Reprod. 2010;25:221-7.

van Rooij IA, Broekmans FJ, Scheffer GJ, Looman CW, Habbema JD, de Jong FH,Fauser BJ, Themmen AP, te Velde ER. Serum antimullerian hormone levels best reflect the reproductive decline with age in normal women with proven fertility: a longitudinal study. Fertil Steril. 2005;83:979-87.

Verhagen TE, Hendriks DJ, Bancsi LF, Mol BW, Broekmans FJ. The accuracy of multivariate models predicting ovarian reserve and pregnancy after in vitro fertilization: a metaanalysis. Hum Reprod Update. 2008;14:95-100.

Visser JA, Themmen AP. Anti-Müllerian hormone and folliculogenesis. Mol Cell Endocrinol. 2005;234:81-6.

Zegers-Hochschild F, Schwarze JE, Crosby JA, Musri C, Urbina MT; Latin American Network of Assisted Reproduction (REDLARA). Assisted reproductive techniques in Latin America: The Latin America Registry, 2013. JBRA Assist Reprod. 2016; 20:49-58. 